\title{
PEMBERDAYAAN EKONOMI MELALUI WAKAF
}

\author{
Solikhul Hadi \\ Sekolah Tinggi Agama Islam Negeri (STAIN) Kudus \\ e-mail: solikhul623@gmail.com
}

\begin{abstract}
Waqf has an economic value where waqf is a potential source of funds for people who need to be developed, utilized, and managed professionally to obtain optimal results. In order to mobilize the potential of waqf, a partnership should be made of the endowments established by the community and the representative bodies established by the Government. The purpose of waqf regulation from the economic aspect is to improve the welfare of Muslims and the Indonesian nation. In addition, to accommodate the growing potential of waqf that is increasingly diverse in line with modern economy such as cash waqf. There are several obstacles that impede the implementation of cash waqf in accordance with the provisions of Law no. 41 of 2004, among which are; first, the Indonesian Waaf Board (BWI) does not have the operational power in the area of sufficient money waqf. Second, the principle used in the implementation of waqf money is too rigid, ie the bank is purely as a bank. Thus, the Wakifwho performs cash waqf is treated the same with other customers.
\end{abstract}

Keywords: Waqf, Economic Empowerment, and Waqf Regulation. 


\section{Pendahuluan}

Dalam tinjauan ekonomi, UU No. 41 Tahun 2004 tentang Wakaf bertujuan untuk pemberdayaan wakaf secara produktif guna kemaslahatan kesejahteraan sosial. Kerangka ide peningkatan pengelolaan wakaf adalah;Potensi wakaf di Indonesia cukup besar, khususnya wakaf yang berwujud tanah yang tersebar di seluruh Indonesia. Data tanah wakaf di seluruh Indonesia sebanyak 320.000 lokasi. Dari jumlah tersebut, hanya sedikit sekali yang dikelola secara produktif sehingga belum banyak dirasakan manfaatnya untuk meningkatkan kesejahteraan umat. Dari jumlah tersebut banyak yang terlantar, terkena gusur, dan diambil oleh orang yang tidak bertanggung jawab.

Dari segi pengelolaan wakaf, penting untuk mendapat perhatian, karena wakaf adalah suatu ibadah dalam agama Islam yang mempunyai nilai ekonomi produktif. Selain itu, wakaf terdiri dari: (1) benda bergerak, antara lain uang tunai, saham, simpanan uang, investasi, produksi, sewa-menyewa, wakaf manfaat dan berjangka; (2) benda tak bergerak, antara lain: masjid/musholla, pendidikan, pesantren, tanah/kebun pertanian, tanah strategis, tanah kuburan, mall, perkantoran, Islamic Center, dan hak paten.

Wakaf merupakan potensi sumber dana umat yang perlu dikembangkan, didayagunakan, dan dikelola secara profesional untuk memperoleh hasil manfaat yang optimal dalam rangka mengentaskan kemiskinan dan mensejahterakan umat.Untuk menggerakkan potensi wakaf perlu kemitraan dari Lembaga Perwakafan yang dibentuk oleh masyarakat dan Badan Perwakafan yang dibentuk oleh Pemerintah di mana anggotanya terdiri dari nazhir di masyarakat dan pemerintah secara profesional.

Sistem pengelolaan, pemberdayaan, dan pengembangan dapat dilakukan melalui antara lain; (1) perencanaan, organizing, pelaksanaan yang amanah dan profesional serta pengawasan yang dapat dipertanggungjawabkan; (2) pendayagunaan dan penanaman modal (investasi) kemitraan, kerjasama dengan 
lembaga perbankan, lembaga keuangan, baik dalam negeri maupun luar negeri.

Diperlukan dukungan dan kemauan politik pemerintah yang besar antara lain; dengan cara memprakarsai, memfasilitasi, mendanai, mengkoordinasikan antar instansi terkait seperti dengan Departemen Keuangan, Departemen Kehakiman dan HAM, Departemen Perdagangan, Departemen Luar Negeri, Badan Pertanahan Nasional, Bursa Efek, LSM, Perguruan Tinggi, Pakar Cendikia, dan ulama serta Dewan Perwakilan Rakyat (DPR) untuk pengembangan dan pendayagunaan secara optimal (Lampiran Surat Menteri Agama kepada Presiden, Nomor: MA/320/2002).

\section{Pembahasan}

\section{Terobosan regulasi}

Ketika Menteri Agama mendapatkan usulan dari Sekretariat Negara untuk menyusun draft RUU Wakaf, maka segera mengirim surat kepada Menteri Kehakiman dan Hak Asasi manusia untuk segera melakukan pembaharuan perundangundangan wakaf. Secara konsisten, dalam surat itu Menteri Agama menyebutkan latar belakang aspek ekonomi produktif dalam wakaf; bahwa pengelolaan wakaf di tanah air memiliki peluang dan prospek pengembangan yang positif, baik dari segi kuantitas maupun pemanfaatannya; perkembangan wakaf pada waktunya akan mengarah menjadi kegiatan investasi dan ekonomi produktif dalam rangka pengentasan kemiskinan dan memajukan kesejahteraan masyarakat, sebagaimana yang telah berjalan di beberapa negara muslim seperti Arab Saudi, Mesir, Tunisia, Turki, Bangladesh dan lain-lain.

Dijelaskan pula, tujuan penyusunan RUU tentang Wakaf dari aspek ekonomi, di antaranya; pada huruf (c) meningkatkan kesejahteraan umat Islam dan bangsa Indonesia; pada huruf (g) untuk menampung berkembangnya potensi wakaf yang semakin beragam sejalan dengan perekonomian modern, seperti 
wakaf tunai, wakaf obligasi, wakaf surat berharga, wakaf atas Hak Kekayaan Intelektual (HAKI) dan lain-lain (Lampiran Surat Menteri Agama kepada Presiden, Nomor: MA/320/2002).

Urgensi wakaf produktif juga disampaikan Menteri Agama ketika mengirim surat permohonan persetujuan prakarsa penyusunan RUU tentang Wakaf kepada Presiden. Dalam surat permohonan itu disertakan latar belakang penyusunan RUU tentang Wakaf dari aspek ekonomi, pada nomor 2 huruf (b) disebutkan; ketentuan mengenai perwakafan yang tercantum dalam perundang-undangan tersebut ( UU No. 5 Tahun 1960; PP No. 28 Tahun 1977; dan Inpres No. 1 Tahun 1991/KHI, penulis) belum dapat dijadikan landasan hukum yang cukup kuat untuk mengatur dan menyelesaikan berbagai persoalan yang menyangkut perwakafan yang dihadapi oleh lembaga keagamaan yang bertindak sebagai nazhir. Sementara itu akhirakhir ini semakin besar kecenderungan masyarakat untuk melakukan perbuatan hukum berupa wakaf uang, yang belum ada pengaturannya dalam peraturan perundang-undangan, padahal wakaf uang itu dinilai secara ekonomi dapat dipergunakan sebagai sarana pengembangan penghidupan dan kehidupan masyarakat (Surat Menteri Agama kepada Presiden, Nomor: MA/25/2003).

Menteri Kehakiman dan Hak Asasi Manusia juga mendukung gagasan RUU tentang Wakaf dalam rangka pengembangan ekonomi produktif melalui rekomendasi atas usul prakarsa penyusunan RUU tentang Wakaf. Dalam surat rekomendasi itu, disampaikan pertimbangan dari hasil rapat, pada poin 2 disampaikan; akhir-akhir ini terdapat kecenderungan untuk melakukan perbuatan hukum berupa wakaf tunai (cash waqf) yang dinilai sebagai cara yang lebih praktis untuk berwakaf dan memiliki prospek ekonomi yang cukup baik (www.syariahmandiri.co.id). Perluasan obyek wakaf berupa benda bergerak tersebut yang secara hukum berkaitan pula dengan masalah-masalah keuangan pada umumnya memerlukan pengaturan cermat, karena itu perlu diatur dengan undang- 
undang (Surat Menteri Kehakiman dan HAM kepada Presiden, Nomor: M.UM.01.06.30).

Mustafa E Nasution, dari Universitas Indonesia, menyatakan pendapatnya; kalau kita bicara wakaf harusnya kita bicara ekonomi Islam sebagai upaya untuk menandingi sistem ekonomi kapitalis yang sudah dirasakan ketidakadilannya. Menurutnya, dalam pengelolaan wakaf uang agar sesuai dengan prinsip Syariah, sehingga bisa menjangkau semua lapisan masyarakat, baik yang kaya maupun tidak. Senada dengan Mustafa, Dr. Mulya Siregar, dari Bank Indonesia, dalam acara tersebut juga mendukung pengelolaan wakaf tunai, seraya menegaskan agar pengelolaan wakaf tunai yang diperoleh dari dana masyarakat diperlukan pengelolaan secara profesional, transparan, dan accountable.

Pada saat DPR RI menyelenggarakan Rapat Dengar Pendapat Umum (RDPU) dengan Ormas Islam, maka muncul pandangan-pandangan tentang RUU Wakaf dalam tinjauan ekonomi dari berbagai Ormas Islam di Indonesia (Risalah DPR RI, 26 Agustus 2004: RDPU tentang Wakaf bersama Ormasormas Islam). MUI yang diwakili oleh Dr. KH. Anwar Ibrahim dan H. Amidhan, menyatakan pendapatnya bahwa sejarah telah membuktikan sesungguhnya wakaf sebagai institusi dalam Islam telah memiliki peran yang sangat siginfikan dalam menunjang kesejahteraan, terutama di bidang pendidikan, kesehatan, dakwah, dan pemberdayaan ekonomi umat. Ditambahkan, wacana wakaf tunai sesungguhnya sudah direspon secara positif oleh Komisi Fatwa MUI dengan keluarnya fatwa tentang wakaf uang pada tanggal 11 Mei 2002 M/ 28 Shafar 1423 H. Hal tersebut sebagai upaya MUI mendorong pengembangan ekonomi di bidang wakaf, khususnya yang terkait dengan uang. Sebagai pilar penting dalam pengembangan ekonomi, wakaf uang dan wakaf benda bergerak lainnya harus mendapatkan perhatian secara serius oleh semua pihak, khususnya pemerintah yang memiliki fungsi regulator 
(Naskah Pandangan MUI dalam RDPU tentang Wakaf bersama Ormas-ormas Islam).

Pengurus Besar Nahdlatul Ulama (PBNU) dalam kesempatan itu, menyampaikan pandangannya terkait dengan RUU Wakaf dalam tinjauan ekonomi. PBNU menyambut gembira dan menyampaikan terima kasih kepada semua pihak yang terkait dengan pembahasan RUU tentang Wakaf, karena PBNU melihat bahwa peraturan perundang-undangan tentang pengaturan dan pengelolaan wakaf memerlukan penyempurnaan, meskipun agak terlambat. Mengingat lahan dan potensi wakaf di Indonesia cukup besar dan memberikan banyak harapan untuk dimanfaatkan secara optimal guna kesejahteraan masyarakat, maka perlu diatur secara khusus. Selama ini, wakaf diatur dalam beberapa pasal UU No. 5 Tahun 1960 (UUPA) dan PP No. 28 Tahun 1977. Kekayaan wakaf di Indonesia yang sangat banyak lebih dimanfaatkan secara konsumtif seperti masjid, mushalla, kuburan, pesantren dan lainlain. Oleh karena itu, dalam rangka meningkatkan potensi wakaf secara produktif, maka tidak ada alasan lain untuk menunda pengesahan RUU Wakaf ini (Naskah Pandangan PBNU dalam RDPU tentang Wakaf bersama Ormas-ormas Islam).

Persatuan Islam (Persis) menyatakan sangat menantikan kehadiran UU tentang Wakaf. Bagi Persis yang memiliki pengalaman panjang dalam pengelolaan wakaf, menganggap peraturan perundang-undangan tentang wakaf pada saat ini masih kurang memadai. Apalagi jika dikaitkan dengan adanya kecenderungan umum pengembangan wakaf produktif. Di Negara kita kekayaan wakaf sangat besar, namun yang kita lihat dan rasakan sampai saat ini masih belum memberikan dampak kesejahteraan yang baik bagi umat Islam. Oleh karena itu, dalam rangka meningkatkan peran wakaf di masa mendatang perlu dipayungi sebuah UU khusus agar pengelolaan wakaf lebih baik dan meningkat demi kesejahteraan banyak (Naskah Pandangan PERSIS dalam RDPU tentang Wakaf bersama Ormasormas Islam). 
PP Muhammadiyah menegaskan, RUU Wakaf setelah ditelaah secara umum sudah sangat baik dan siap untuk dibahas serta disahkan menjadi UU. Bagi Muhammadiyah yang selama ini sudah dilibatkan dalam proses penyusunan oleh pemerintah, RUU Wakaf dianggap sudah cukup ideal dan sudah memenuhi aspek yuridis dalam mengayomi pengelolaan wakaf secara produktif. Di Lingkungan Muhammadiyah sendiri sesungguhnya sudah dimulai kerja-kerja pengelolaan wakaf secara produktif. Namun, sampai saat ini belum memberikan hasil yang maksimal disebabkan oleh kondisi riil masyarakat yang belum memahami wakaf sebagai ibadah sosial. Di sisi lain, keberadaan benda-benda wakaf banyak dikelola oleh nazhir wakaf perseorangan yang minim atas profesionalitas (Naskah Pandangan Muhamadiyah dalam RDPU tentang Wakaf bersama Ormas-ormas Islam.

Dukungan atas konsep wakaf produktif yang dikemukakan oleh Menteri Agama, juga mengalir dari lembaga nirlaba Dompet Dhuara Republika (DDR) pada kesempatan Rapat Dengar Pendapat Umum (RDPU) dengan DPR (Risalah DPR RI). Menurut DDR, sebagai sebuah lembaga yang sudah lama bekecimpung dalam pengelolaan zakat, infak dan sedekah serta uang tunai, DDR memiliki pandangan terhadap RUU Wakaf agar kelak jika disahkan menjadi UU dapat memberikan perlindungan terhadap harta-harta dan menjadi pemicu bagi tumbuhnya semangat pemberdayaan wakaf produktif (Naskah Pandangan DDR dalam RDPU tentang Wakaf bersama BAZNAS/LAZNAS).

Hal serupa juga dikemukakan oleh LAZ Pos Keadilan Peduli Umat (PKPU). Lembaga itu memberikan sumbang saran; sebelum RUU wakaf disahkan, sebaiknya dipahami betul landasan wakaf secara mendalam. Sehingga, wakaf dijabarkan dan dikelola secara lebih operasional dan tidak ditempatkan sebagai ajaran yang hanya berhenti pada aspek ibadah belaka, namun sesungguhnya wakaf memiliki tujuan dan substansi terhadap kesejahteraan sosial. Untuk itu, dalam menyusun RUU Wakaf harus lebih matang, dan kalau memungkinkan DPR tidak terburu-buru untuk 


\section{Solikhul Hadi}

membahas. Lebih baik mengkaji lebih mendalam terlebih dahulu, namun akan menghasilkan UU Wakaf yang komprehensif dan dapat mendorong bagi tumbuhnya semangat pemberdayaan wakaf secara produktif (Naskah Pandangan LAZ PKPU dalam RDPU tentang Wakaf bersama BAZNAS/LAZNAS).

Dalam Rapat Kerja Komisi VI DPR RI dengan Menteri Agama, masing-masing fraksi menyampaikan tanggapannya atas RUU Wakaf dalam perspektif pengembangan ekonomi produktif (Risalah DPR RI).

Fraksi Partai Golkar (FPG) menyatakan; secara sosiologis, wakaf merupakan bagian dari sumber kekayaan yang dapat dijadikan sebagai sarana untuk melakukan kebajikan-kebajikan umum, baik kebajikan ibadah mahdhah maupun ibadah sosial. Oleh karena itu penting dilakukan pengaturan dan penataan, baik yang bersifat administratif, maupun manajerial yang terkait dengan wakaf (Naskah Pandangan FPG dalam Rapat Kerja antara Komisi VI DPR RI dengan Pemerintah).

Fraksi Partai Demokrasi Indonesia Perjuanangan (FPDIP) memberikan respon terhadap RUU Wakaf; bagi FPDIP wakaf adalah suatu hukum di mana seseorang memisahkan sebagian harta bendanya untuk dimanfaatkan guna kepentingan ibadah, baik ibadah mahdhah maupun sosial. Oleh karena itu harus didukung dan digalakkan pelaksanaannya di tengah-tengah masyarakat (Naskah Pandangan FPDIP dalam Rapat Kerja antara Komisi VI DPR RI dengan Pemerintah).

Fraksi Kebangkitan Bangsa (FKB) berpandangan; harta wakaf itu bisa menjadi aset yang produktif dan bermanfaat besar bagi kehidupan umat kalau dikelola dan diarahkan oleh sebuah institusi atau perorangan yang memiliki jiwa amanah, bertanggung jawab dan profesional dalam mengelola harta wakaf. UU tentang Wakaf ini diharapkan mampu mengarahkan spirit pengelolaan harta wakaf ke arah idealisme seperti itu (Naskah Pandangan FKB dalam Rapat Kerja antara Komisi VI DPR RI dengan Pemerintah). 
Fraksi Reformasi (FR) menyampaikan tanggapannya; RUU Wakaf diharapkan bisa memberi jaminan untuk kesinambungan dan optimalisasi pengelolaan dan pemanfaatan benda wakaf. Prinsip utama harus sesuai dengan ekonomi Syari'ah Islamiyyah (Naskah Pandangan FR dalam Rapat Kerja antara Komisi VI DPR RI dengan Pemerintah).

Fraksi TNI/POLRI memberikan pandangannya; peraturan yang sudah ada kurang memadai karena permasalahan wakaf yang mengemuka di masyarakat atau yang dihadapi lembaga keagamaan yang bertindak sebagai nadzir dari waktu ke waktu semakin berkembang. Di samping itu wakaf perlu dikelola secara efektif dan efisien karena memiliki potensi dan manfaat ekonomi guna kepentingan ibadah dan memajukan kesejahteraan umum. Masyarakat amat membutuhkan pengaturan mengenai wakaf ini, baik wakaf produktif maupun wakaf uang yang selama ini belum diatur dalam regulasi wakafNaskah Pandangan TNI/POLRI dalam Rapat Kerja antara Komisi VI DPR RI dengan Pemerintah.

Secara umum dapat disimpulkan bahwa seluruh kekuatan politik yang tergabung di dalam Komisi VI DPR RI pada prinsipnnya sependapat bahwa RUU tentang Wakaf dapat dijadikan sarana pengembangan wakaf produktif. Argumentasi yang mereka bangun juga hampir sama yaitu; dimensi wakaf ada dua; dimensi vertikal (ibadah mahdhah) dan dimensi horisontal (ibadah sosial). Pada dimensi ibadah yang disebut terakhir itu, selama ini kurang diberdayakan karena belum adanya regulasi yang memadai.

Ketegasan dukungan partai-partai politik terhadap RUU tentang Wakaf dalam kaitan pemberdayaan ekonomi produktif disampaiakn dalam Rapat Paripurna DPR RI untuk Pengambilan Keputusan RUU tentang Wakaf. Rapat Paripurna ini merupakan kulminasi dari rangkaian proses pengusulan, penyusunan, sampai pengesahan. Dalam Rapat Paripurna ini semua fraksi partai politik menyampaikan pandangannya (Risalah DPR RI). 
Fraksi Partai Golkar (FPG) memberikan tanggapan; kesejahteraan dan ekonomi umat, bisa digerakkan atau dipacu, serta diakselerasikan oleh adanya UU ini. Adanya inovasi tentang sumber-sumber potensi pemberdayaan ekonomi dan kesejahteraan umat seperti wakaf uang merupakan suatu keberanian bahkan terobosan dari pemerintah yang secara jeli telah melihat peluang ini untuk dapat dijadikan sumbangsih bagi kehidupan bermasyarakat, berbangsa, dan beragama (Naskah FPG Pandangan Umum dan Pengesahan Rapat Paripurna Terbuka DPR RI).

Fraksi Partai Demokrasi Indonesi Perjuangan (FPDIP) menyampaikan pandangan akhirnya; masyarakat maju di masa depan diharapkan akan semakin terus berkembang dengan kultur yang telah diwarisi masa lalu dan masa kini. Khususnya dalam pemberdayaan sifat dan sikap sosial, khususnya dalam hal pemberdayaan dan pemanfaatan ekonomi dan non-ekonomi harta benda wakaf. Sejalan dengan itu, perkembangan sosial masyarakat, khususnya bagi berkembangnya pemikiran dalam pengelolaan harta benda wakaf secara ekonomi produktif, perlu dikembangkan dengan didasarkan atas Syari'ah (Naskah FPDIP Pandangan Umum dan Pengesahan Rapat Paripurna Terbuka DPR RI).

Fraksi Kebangkitan Bangsa (FKB) memberikan tanggapan akhir; dinamika pemaham Islam cukup progresif dengan munculnya perluasan pengertian benda wakaf bukan hanya tanah dan bangunan. Hal ini berimplikasi pada pemberdayaan wakaf sebagai sarana peningkatan ekonomi produktif (Naskah FKB Pandangan Umum dan Pengesahan Rapat Paripurna Terbuka DPR RI).

Fraksi Persatuan Pembangunan (FPP) menyampaikan rasa syukur atas selesainya pembahasan RUU tentang Wakaf ini. Karena, dengan keberadaan peraturan wakaf ini akan memaksimalkan fungsi wakaf sebagai pranata agama yang memiliki potensi dan manfaat ekonomi guna kepentingan ibadah 
dan kepentingan kesejahteraan umum. FPP berharap agar institusi ini (BWI) mampu menjalin kerjasama dengan berbagai pihak yang dipandang penting, guna lebih memaksimalkan potensi ekonominya, untuk kepentingan ibadah dan juga memajukan kesejahteraan umum (Naskah FPP Pandangan Umum dan Pengesahan Rapat Paripurna Terbuka DPR RI).

Fraksi Reformasi (FR) memberikan tanggapan; dalam UU ini dinyatakan sistem, tata cara pengelolaan dan pengembangan benda wakaf yang dilakukan secara produktif, pelaksanaannya harus sesuai dengan peraturan perundang-undangan dan tidak bertentangan dengan prinsip Syari'ah. Berkaitan dengan hal tersebut FR menyatakan, bahwa pengelolaan benda wakaf harus betul-betul untuk mewujudkan sarana ibadah yang dikembangkan untuk mendukung kegiatan ibadah dan kegiatan ekonomi masyarakat (Naskah FR Pandangan Umum dan Pengesahan Rapat Paripurna Terbuka DPR RI).

Fraksi TNI/POLRI memberikan pandangannya; setelah terjadinya krisis multidimensi pada tahun 1997-1998 dalam kehidupan bangsa Indonesia, dampak krisis ekonomi masih berlanjut sampai sekarang, maka peran wakaf menjadi semakin penting sebagai salah satu instrumen untuk meningkatkan kesejahteraan umat. Wakaf tunai/wakaf uang merupakan hal baru dan belum dikenal di masyarakat, maka perlu pengelolaan yang tepat oleh Lembaga Keuangan Syari'ah (LKS) untuk menjamin transparansi, likuiditas, dan akuntabilitas. Di dalam wakaf uang ini harus ada lembaga penjamin, mengingat harta benda wakaf bukan sesuatu yang langsung habis. Lembaga penjamin terhadap wakaf uang adalah untuk mengantisipasi kemungkinan habisnya benda wakaf ini mengalami pailit (Naskah TNI/POLRI Pandangan Umum dan Pengesahan Rapat Paripurna Terbuka DPR RI).

Fraksi Persatuan Daulat Umat (FPDU) menyampaikan; perlunya Lembaga Keuangan Syari'ah (LKS) yang menerbitkan sertifikat wakaf uang. Dengan adanya sertifikat tersebut, maka 
terdapat kepastian dan jaminan terhadap harta benda wakaf untuk tidak disalahgunakan atau disalahperuntukkan (Naskah FPDU Pandangan Umum dan Pengesahan Rapat Paripurna Terbuka DPR RI).

Kepentingan ekonomi dalam pembentukan UU tentang Wakaf, juga disebutkan di dalam konsideran UU No. 41 Tahun 2004 tentang Wakaf. Dalam konsideran itu berbunyi: Menimbang; bahwa lembaga wakaf sebagai pranata keagamaan yang memiliki potensi dan manfaat "ekonomi" perlu dikelola secara efektif dan efisien untuk kepentingan ibadah dan untuk memajukan kesejahteraan umum.

Selain disebutkan di dalam konsideran UU tentang Wakaf, juga diterangkan di dalam Penjelasan atas UU No. 41 Tahun 2004 tentang Wakaf yang dituangkan dalam Tambahan Lembaran Negara Republik Indonesia Nomor 4459. Dalam penjelasan umum disebutkan; salah satu langkah strategis untuk meningkatkan kesjahteraan umum, perlu meningkatkan peran wakaf sebagai pranata keagamaan yang tidak hanya bertujuan menyediakan berbagai sarana ibadah dan sosial, tetapi juga memiliki kekuatan ekonomi yang berpotensi, antara lain, untuk memajukan kesejahteraan umum, sehingga perlu dikembangkan pemanfaatannya sesuai dengan prinsip Syari'ah. Penjelasan berikutnya; ruang lingkup wakaf yang selama ini dipahami secara umum cenderung terbatas pada wakaf benda tidak bergerak, seperti tanah dan bangunan, menurut undang-undang ini wakif dapat pula mewakafkan sebagian kekayaannya berupa harta benda wakaf bergerak, baik berwujud atau tidak, yaitu uang, logam mulia, surat berharga, kendaraan, hak kekayaan intelektual, hak sewa, dan benda bergerak lainnya.

\section{Produk hukum}

Langkah kongkrit menuju pemberdayaan wakaf produktif, tertuang di dalam pasal-pasal UU No. 41 Tahun 2004. Berikut adalah tabel substansi UU Wakaf dalam pemeberdayaan wakaf produktif. 
Tabel 1

Substansi UU Wakaf dalam Pemberdayaan Ekonomi

\begin{tabular}{lrl}
\hline No & Pasal & Substansi \\
\hline 1 & Pasal 5 & $\begin{array}{l}\text { Wakaf berfungsi mewujudkan potensi dan manfaat } \\
\text { ekonomis harta benda wakaf untuk kepentingan }\end{array}$ \\
& & ibadah dan untuk memajukan kesejahteraan \\
& & \\
& &
\end{tabular}

2 Pasal 16 Harta benda wakaf terdiri dari: (a) benda tidak ayat (1) bergerak; dan (b) benda bergerak.

Pasal 16 Benda tidak bergerak sebagaimana dimaksud ayat (2) pada ayat (1) huruf a meliputi: (a) hak atas tanah sesuai dengan ketentuan peraturan perundangundangan yang berlaku baik yang sudah maupun belum terdaftar; (b) bangunan atau bagian bangunan yang berdiri di atas tanah sebagaimana dimaksud pada huruf a; a) tanaman dan benda lain yang berkaitan dengan tanah; b) hak milik atas satuan rumah susun sesuai dengan ketentuan peraturan perundang-undangan yang berlaku; c) benda tidak bergerak lain sesuai dengan ketentuan syari'ah dan peraturan perundang-undangan yang berlaku.

Pasal 16 Benda bergerak sebagaimana dimaksud pada ayat ayat (3) (1) huruf $b$ adalah harta benda yang tidak bisa habis karena dikonsumsi, meliputi: (a) uang; (b) logam mulia; (c) surat berharga; (d) kendaraan; (e) hak atas kekayaan intelektual; (f) hak sewa; dan (g) benda bergerak lain sesuai dengan ketentuan syariah dan peraturan perundang-undangan yang berlaku.

3 Pasal 22 Dalam rangka mencapai tujuan dan fungsi wakaf, harta benda wakaf hanya dapat diperuntukkan bagi: (a) sarana dan kegiatan ibadah; (b) sarana dan kegiatan pendidikan serta kesehatan; (c) bantuan kepada fakir miskin, anak terlantar, yatim piatu, bea siswa; (d) kemajuan dan peningkatan ekonomi umat; dan/atau; (e) kemajuan kesejahteraan umum lainnya yang tidak bertentangan dengan syariah dan peraturan perundang-undangan. 

4 Pasal 28 Wakif dapat mewakafkan benda bergerak berupa uang melalui lembaga keuangan syariah yang ditunjuk oleh Menteri.
5 Pasal 43 Pengelolaan dan pengembangan harta benda ayat (2) wakaf sebagaimana dimaksud pada ayat (1) dilakukan secara produktif.
Pasal 43 Dalam hal pengelolaan dan pengembangan ayat (3) harta benda wakaf yang dimaksud pada ayat (1) diperlukan penjamin, maka digunakan lembaga penjamin syariah.

\section{Hambatan wakaf tunai}

Hasbullah Hilmi (2012: 271-272) dalam penelitiannya berkesimpulan; (a) terdapat keragaman tingkat pemahaman dan penerimaan stakeholder terhadap model wakaf uang yang diatur di dalam UU No. 41 Tahun 2004 tentang Wakaf. Dari keragaman pemahaman dan penerimaan model wakaf uang itu, maka berimplikasi pada penerapan dan juga pengelolaan wakaf uang di lembaga-lembaga keuangan syariah; (b) regulasi wakaf terlampau rigit, yakni adanya keharusan investor melibatkan Lembaga Keuangan Syariah (LKS) baik secara langsung maupun tidak. Dampak yang ditimbulkan dari aturan itu adalah aplikasi wakaf uang menjadi kurang dalam penciptaan keadilan sosial.

Desain UU wakaf menyangkut wakaf uang, kurang mendapat sambutan dari masyarakat. Pemahaman masyarakat menyangkut wakaf uang cukup sederhana, yakni wakaf uang sebagai antara untuk diwujudkan menjadi aset wakaf sosial atau produktif (Hilmi, 2012: 271).

Menurut Hilmi (2012: 264-266) ada beberapa kendala yang menjadi hambatan implementasi wakaf tunai sesuai ketentuan UU No. 41 Tahun 2004, di antaranya; (a) Badan Wakaf Indonesia (BWI) tidak memiliki tenaga operasional di bidang wakaf uang yang cukup memadai; (b) prinsip yang digunakan dalam pelaksanaan wakaf uang terlalu kaku, yaitu bank adalah murni 
sebagai bank. Sehingga, wakif yang melakukan wakaf tunai diberlakukan sama dengan nasabah lainnya; dan (c) sesuai UU No. 41 Tahun 2004 Pasal 59 disebutkan; "Dalam rangka pelaksanaan tugas Badan Wakaf Indonesia, Pemerintah wajib membantu biaya operasional. Namun, dalam kenyataannya dana yang diberikan oleh Kementerian Agama kepada BWI terlalu kecil.

\section{Simpulan}

Wakaf merupakan potensi sumber dana umat yang perlu dikembangkan, didayagunakan, dan dikelola secara profesional untuk memperoleh hasil manfaat yang optimal dalam rangka mengentaskan kemiskinan dan mensejahterakan umat.Untuk menggerakkan potensi wakaf perlu kemitraan dari Lembaga Perwakafan yang dibentuk oleh masyarakat dan Badan Perwakafan yang dibentuk oleh Pemerintah. Legislasi UU No. 41 Tahun 2004 tentang Wakaf bertujuan untuk pemberdayaan wakaf secara produktif guna kemaslahatan kesejahteraan sosial.Pada saat DPR RI menyelenggarakan Rapat Dengar Pendapat Umum (RDPU) dengan Ormas Islam dan Parpol, maka terlihat adanya dukungan yang luar biasa untuk mengimplementasikan regulasi wakaf untuk tujuan ekonomi produktif melalui wakaf tunai.

Terdapat beberapa kendala yang menjadi hambatan implementasi wakaf tunai sesuai ketentuan UU No. 41 Tahun 2004, di antaranya; (a) Badan Wakaf Indonesia (BWI) tidak memiliki tenaga operasional di bidang wakaf uang yang cukup memadai; (b) prinsip yang digunakan dalam pelaksanaan wakaf uang terlalu kaku, yaitu bank adalah murni sebagai bank. Sehingga, wakif yang melakukan wakaf tunai diberlakukan sama dengan nasabah lainnya; dan (c) sesuai UU No. 41 Tahun 2004 Pasal 59 disebutkan; "Dalam rangka pelaksanaan tugas Badan Wakaf Indonesia, Pemerintah wajib membantu biaya operasional. Namun, dalam kenyataannya dana yang diberikan oleh Kementerian Agama kepada BWI terlalu kecil. 
Solikhul Hadi

\section{Daftar Pustaka}

Abdurrahman, Kompilasi Hukum Islam di Indonesia, Akademiko Pressindo, Jakarta, 1992.

Abdurrahman, Masalah Perwakafan Tanah Milik dan Kedudukan Tanah Wakaf di Negara Kita, Alumni, Bandung, 1979.

Achmad Djunaidi, dan Thobieb Al-Asyhar, Menuju Era Wakaf

Produktif, Mumtaz Publishing, Jakarta, 2007.

Ahmad Azhar Basyir, Hukum Islam tentang Wakaf, Ijarah dan Syirkah, Al- Ma'arif, Bandung, 1986.

Depag RI, Panduan Pemberdayaan Tanah Wakaf Produktif Strategis di Indonesia, Direktorat Pemberdayaan Wakaf Dirjen Bimas Islam, Jakarta, 2007c.

Depag RI, Paradigma Baru Wakaf di Indonesia, Direktorat Pemberdayaan Wakaf Dirjen Bimas Islam, Jakarta, 2007a.

Depag RI, Pedoman Pengelolaan Wakaf Tunai, Direktorat Pemberdayaan Wakaf Dirjen Bimas Islam, Jakarta, 2007d.

Depag RI, Strategi Pengembangan Wakaf Tunai di Indonesia, Direktorat Pemberdayaan Wakaf Dirjen Bimas Islam, Jakarta, 2007b.

Depag RI, Undang-Undang Republik Indonesia Nomor 41 Tahun 2004 tentang Wakaf, Dirjen Bimas Islam dan Urusan Haji, Jakarta, 2004.

Hasbullah Hilmi, Dinamika Pengelolaan Uang Wakaf (Studi tentang Perilaku Pengelolaan Wakaf Uang Pasca Pemberlakuan UU No. 41 Tahun 2004), Disertasi Pasca Sarjana IAIN Walisongo Semarang, 2012.

Mohammad Daud Ali, Sistem Ekonomi Islam, Zakat dan Wakaf, Universitas Indonesia Press, Jakarta, 1988. 